\title{
Kaposi sarcoma herpesvirus (KSHV)-associated lymphomas are associated with markedly elevated serum IL-10, elevated IL-6, IL-17 and circulating KSHV
}

\author{
Thomas S Uldrick ${ }^{1 *}$, Mark N Polizzotto ${ }^{1}$, Kathleen Wyvill ${ }^{1}$, Karen Aleman ${ }^{1}$, Vickie Marshall ${ }^{4}$, Richard F Little ${ }^{1}$, \\ Armando Filie ${ }^{2}$, Mark Raffeld ${ }^{2}$, Seth M Steinberg ${ }^{3}$, Stefania Pittaluga ${ }^{2}$, Denise Whitby ${ }^{4}$, Robert Yarchoan ${ }^{1}$
}

From 13th International Conference on Malignancies in AIDS and Other Acquired Immunodeficiencies (ICMAOI)

Bethesda, MD, USA. 7-8 November 2011

\section{Background}

KSHV, also called human herpesvirsus-8 (HHV8), is the etiologic agent of primary effusion lymphoma (PEL) (including extracavitary variant), and large B-cell lymphoma arising in HHV8-associated multicentric Castleman disease (together, KSHV-associated non-Hodgkin lymphoma (KSHV-NHL). Additional KSHV-associated diseases include: Kaposi sarcoma (KS), a form of multicentric Castleman disease (KSHV-MCD), and a proposed KSHV-associated inflammatory cytokine syndrome (KICS). Like KSHV-MCD, inflammatory symptoms are common in KSHV-NHL. We compared an array of inflammatory and angiogenic cytokines, chemokines, growth factors, and select clinical laboratory values between HIV-infected patients with KSHV-NHL and other lymphomas (HIV-lymphoma).

\section{Methods}

Patients were enrolled in HAMB and/or NIAID protocols. Cases had KSHV-NHL; controls other HIV-lymphoma. Clonality of PEL diagnosed from effusions was confirmed by PCR for immunoglobin rearrangements. Serum was evaluated by ELISA for IFN- $\gamma$, IL-1 $\beta$, IL-6, IL-8, IL-10, IL12p70, TNF- $\alpha$, IL-17, VEGF-A, (Meso-Scale Discovery, Gathersberg, MD), CXCL1, VEGF-C (R\&D Systems, Minneapolis, MN). In patients with KSHV-NHL, peripheral blood mononuclear cell associated KSHV viral load was

\footnotetext{
* Correspondence: uldrickts@mail.nih.gov

${ }^{1} \mathrm{HIV}$ and AIDS Malignancy Branch, Center for Cancer Research, National

Cancer Institute, National Institutes of Health, Bethesda, MD, USA

Full list of author information is available at the end of the article
}

measured. Clinical data included demographics, CD4 count, albumin, platelets, hemoglobin, and c-reactive protein (CRP). Comparison of each parameter between patients with KSHV-NHL and other HIV-lymphoma employed an exact form of the Wilcoxon rank-sum test. P-values are 2 -sided, with $\mathrm{p} \leq 0.01$ considered statistically significant, and $0.01<\mathrm{p}<0.05$ considered strong trends.

\section{Results}

Subjects:13 KSHV-NHL cases: 12 men, 1 woman. Median age 44, (IQR 39-55). 4 white, 4 Hispanic, 3 African-American, 2 African. PEL (8), extracavitary variant PEL (3), large B-cell lymphoma arising in HHV8-associated MCD (2, both with large effusions), history pathology confirmed KSHV-MCD (4). 28 HIV-associated lymphoma controls: 23 men, 5 women. Median age 38 (IQR 35-46). 17 white, 4 Hispanic, 6 African-American, 1 African. Histologies: primary central nervous system lymphoma (13), diffuse large B-cell lymphoma (DLBCL) (10), Hodgkin disease (1), Burkitt lymphoma (2), plasmablastic lymphoma (1), EBV+ large B-cell lymphoma NOS (1). KSHV-NHL subjects had elevated KSHV viral load, [median 2812 copies $/ 10^{6}$ cells (IQR 186-115,789)] and CRP [median $51 \mathrm{mg} / \mathrm{L}$ (IQR 4567)]. Compared to other HIV-lymphomas, patients with KSHV-NHL have higher CD4 counts (median CD4 133 vs. 29 cells/uL, $\mathrm{p}=0.002$ ), hypoalbuminema (median albu$\min 1.9$ vs. $3.5 \mathrm{mg} / \mathrm{dL}, \mathrm{p}=0.0034)$ ), and trend towards more severe anemia, thrombocytopenia, and hyponatremia. KSHV-NHL is associated with elevated circulating KSHV, marked elevations in IL-10 (513 vs. $12.2 \mathrm{pg} / \mathrm{mL}$, $\mathrm{p}<0.0001)$, elevations in IL-6 (29 vs. $4.1 \mathrm{pg} / \mathrm{mL}$, 
$\mathrm{p}=0.0013)$, IL-17 (1.6 vs. $0.5 \mathrm{pg} / \mathrm{mL}, \mathrm{p}=0.0074)$, and trends towards increased IFN- $\gamma$ and IL- $1 \beta$.

\section{Conclusions}

Inflammatory cytokines are important n KSHV-NHL pathogenesis and symptomatology. Clinical and translational studies evaluating these abnormalities in KSHVassociated malignancies are ongoing.

Author details

${ }^{1}$ HIV and AIDS Malignancy Branch, Center for Cancer Research, National Cancer Institute, National Institutes of Health, Bethesda, MD, USA.

2 Laboratory of Pathology, Center for Cancer Research, National Cancer Institute, National Institutes of Health, Bethesda, MD, USA. ${ }^{3}$ Biostatistics and Data Management Section, Center for Cancer Research, National Cancer Institute, National Institutes of Health, Bethesda, MD, USA. ${ }^{4}$ AIDS and Cancer Virus Program, SAIC-Frederick, National Cancer Institute, National Institutes of Health, Frederick, MD, USA.

Published: 19 April 2012

Cite this article as: Uldrick et al:: Kaposi sarcoma herpesvirus (KSHV)associated lymphomas are associated with markedly elevated serum IL10, elevated IL-6, IL-17 and circulating KSHV. Infectious Agents and Cancer 2012 7(Suppl 1):P39.

Submit your next manuscript to BioMed Central and take full advantage of:

- Convenient online submission

- Thorough peer review

- No space constraints or color figure charges

- Immediate publication on acceptance

- Inclusion in PubMed, CAS, Scopus and Google Scholar

- Research which is freely available for redistribution

Submit your manuscript at www.biomedcentral.com/submit 